\title{
Exploring the Needs and Expectations of International Students towards The National University of Malaysia (UKM)
}

Mohammed Fadel Arandas ${ }^{1}$

${ }^{1}$ Affiliation not available

July 7, 2021

\section{Hosted file}

Exploring the Needs and Expectations of International Students towards The National University of Malay available at https://authorea.com/users/424343/articles/529446-exploring-the-needs-andexpectations-of-international-students-towards-the-national-university-of-malaysia-ukm 